Acta Universitatis Wratislaviensis No 3836

Anglica Wratislaviensia LVI, Wrocław 2018

DOI: 10.19195/0301-7966.56.8

\author{
Paulina Pająk \\ ORCID: 0000-0001-6911-1284 \\ University of Wroclaw \\ paulina.pajak@uwr.edu.pl
}

\title{
Housed Memories: Spatial and Temporal Portraits in Virginia Woolf's The Voyage Out
}

\begin{abstract}
Neurocognitive research has confirmed that people perceive and remember the "rooms of their own" similarly to their own bodies. These psychological discoveries yield important new insights into the oeuvre of Virginia Woolf, an avid diarist, flâneuse and experimenter, preoccupied with gendered memory and space available to women in the early $20^{\text {th }}$ century. While there exists an important and growing body of work on Woolf's interest into women's emancipation and politics of space, the gendered connection between spatial and temporal aspects of her works remains a little researched area, particularly in the context of neurocognitive theory of memory. This paper argues that in The Voyage Out the representations of the protagonist, Rachel Vinrace, are structured around the processes of autobiographical remembering and spatial perception, as her private rooms serve as loci of her memory and identity. It is then possible to interpret Rachel's rooms as her spatial portraits, which perceived by other characters tell their inhabitant's life story. A similar role could be attributed to the (auto)biographical memory, which preserves their owner's temporal portrayals in particular moments of her life.
\end{abstract}

Keywords: Virginia Woolf, The Voyage Out, space, place, memory, neurocognitive theory

In the diary entry on 30th August 1923, Virginia Woolf discusses her "tunnelling method" first used in Mrs Dalloway ("The Hours"): "I'm thinking furiously about Reading \& Writing. I have no time to describe my plans. I should say a good deal about The Hours, \& my discovery; how I dig out beautiful caves behind my characters; I think that gives exactly what I want; humanity, humour, depth. The idea is that the caves shall connect, \& each comes to daylight at the present moment" (1981: 263). Distinct features of Woolf's oeuvre are formal experiments in portraiture: from "countless creative biographical sketches" in her essayism (Bruś 2011: 12) to the stream of consciousness and polyphony of her mature works. The search for new forms of characters' representations is also visible in Woolf's early 
novels, which present their heroines' complex nature in a series of spatial and temporal portraits. ${ }^{1}$

This paper sets out to examine Woolf's early representations of women in the context of spatial and temporal aspects of her debut novel The Voyage Out. The narrative voice persuades the readers that "the rooms in which people live are apt to give off something of the same shock as their faces when seen for the first time" (Woolf 1991: 178). It is then tempting to interpret the rooms of Rachel Vinrace, the heroine, as her spatial portrayals, which perceived by other characters tell their inhabitant's life story. A similar role could be attributed to (auto)biographical memory, which preserves their owner's temporal portraits in particular moments of her life.

\section{Private space and autobiographical memory in Woolf's oeuvre}

The themes of gendered memory and space are recurrent in Woolf's novels. While Suzanne Nalbantian observes that Woolf focuses on the autobiographical memory, also in the metacognitive dimension (2003: 79), Evelyn Ender numbers the writer among "the exemplary architects and painters of memory images," together with Proust (2005: 241-242). The visual and kinesthetic sensitivity of the novelist inspires the intense and multidimensional spatiality of her works. From Woolf's essayistic flaneuse to the heroines of her novels immersed in the macrocosm of London, urban space reflects the boundaries women need to "trespass" in the early $20^{\text {th }}$ century. After the spatial turn in Humanities, the question of space in Woolf's oeuvre has been the focus of considerable research. ${ }^{2}$ As Anna Snaith and Michael H. Whitworth notice:

Woolf's fictional and non-fictional writing is consistently concerned with the politics of spaces: national spaces, civic spaces, private spaces, or the textual spaces of the writer/printer [...]. While private, domestic space, the woman's room, is at the hub of her feminist politics, it is from this room that she became one of the key writers of urban modernity, particularly in its feminist articulation. (2007: 1)

Though these scholars introduce the dichotomy "between abstract, conceptual space and locatable, material places," they emphasize both that Woolf's writings call it into question and that their volume Locating Woolf was "the first book-length study of Woolf and place" (Snaith and Whitworth 2007: 4-5).

${ }^{1}$ On the relationship between characters and their portraits, see, e.g. Mieke Bal, who states: "When we come across a detailed portrait of a character that has already been mentioned, we are justified in saying that that information - that portrait — 'belongs to' the character, it 'creates' the character, maps it out, builds it up" (2009: 114).

2 See for example: E.F. Evans and S.E. Cornish (eds.). 2010. Woolf and the City. Clemson UP; S.S. Friedman. 2011. Mappings: Feminism and the Cultural Geographies of Encounter. Princeton UP; L. Larsson. 2017. Walking Virginia Woolf's London. Palgrave Macmillan; A. Thacker. 2009. Moving Through Modernity: Space and Geography in Modernism. Manchester UP. 
While the issue of women's "rooms of their own" has been thoroughly examined in the context of Woolf's feminist politics, the portrayals of women's private space in novels received less critical attention. Nonetheless, the conflicts between the heroines' inner worlds, confined to their rooms and "communal reality" in Woolf's early novels were interpreted by Urszula Terentowicz-Fotyga in her monograph of spatial relations in Woolf's fiction (2006: 19-29). The formative influence of such rooms on autobiographical memory has only begun to be explored, for example by Suzana Zink, who analyzed the connections between space and autobiographical memory in Woolf's memoir "A Sketch of the Past"3 (2013: 206-235).

The complex affinity between the autobiographical memory and spatiality was considered by Gaston Bachelard, who wrote: "Not only our memories, but the things we have forgotten are 'housed.' Our soul is an abode. And by remembering 'houses' and 'rooms,' we learn to 'abide' within ourselves [...]. [T] he house images move in both directions: they are in us as much as we are in them" (1969: XXXIII). ${ }^{4}$ Bachelard's poetic metaphor has been consolidated by neurocognitivists: people perceive and remember their rooms similarly to their bodies, using egocentric reference systems:

Egocentric reference systems are those in which location is specified with respect to the observer. Examples include (but are not limited to) retinal, head, and body coordinates. Environmental reference systems are those in which location is specified with respect to objects other than the observer [...] A growing body of evidence suggests that memories of roomsized and smaller layouts are mentally represented in terms of egocentric reference systems. (Mou and McNamara 2002: 162)

The environmental and egocentric reference systems have their functional equivalents in the autobiographical memory processes: the observer memory, in which people perceive their former actions from the perspective of an outsider (third-person perspective), and field memory, which involves "seeing" the past through one's own eyes (first-person perspective) (Eich et al. 2009: 2239). Peter Middleton and Tim Woods thus explain these differences: "[a] field memory occurs when the rememberer witnesses the scene of a memory from the standpoint in which it was lived, whereas in an observer memory the memory shows oneself within the scene which is then witnessed as a whole" (2000: 89). Though in fiction the observer memory and field memory are generally represented as third- and first-person narration respectively, these perspectives could be juxtaposed, as in the stream of consciousness.

Moreover, both space and memory have their gender dimension. The temporal and spatial aspects of gender have been analyzed by scholars inspired by Judith Butler's performative theory. While the geographer Doreen Massey provided new

3 This dissertation has been recently published: S. Zink. 2018. Virginia Woolf's Rooms and the Spaces of Modernity. New York: Palgrave Macmillan.

${ }^{4}$ Nevertheless, while the phenomenological search aimed at the essential and unchanging, modernist experiments in portraiture focused on the mutability of identity and its construction. 
insights into the gendering of space and place, ${ }^{5}$ the psychologist Robin Fivush has examined gendered autobiographical memory. ${ }^{6}$ Such gendered perspective constitutes a crucial aspect of Woolf's works, for example, Laura Marcus notes about The Voyage Out: "shifting perspective are also an aspect of the novel's concern with relativity, with the varying relations of time and space, and with the ways in which what Woolf called the 'difference of view' (referring [...] to the different ways in which men and women see the world) commands a difference of values" (2004: 14).

Taking into consideration the spatial and temporal dimensions of Woolf's fiction, this paper argues that in The Voyage Out the representation of female protagonist relies mostly on gendered autobiographical memory and spatiality. It presents the analysis of Rachel's portraits, focusing on the narrative shifts from observer to field memory, as well as from egocentric to environmental perspectives with reference to space.

\section{Fleeting portraits in The Voyage Out}

In February 1909 in a reply to Clive Bell's letter criticizing an explicitly feminist draft of The Voyage Out, Woolf emphasizes: "I think I gather courage as I go on. The only possible reason for writing down all this, is that it represents roughly a view of one's own. My boldness terrifies me" (1975: 383). The phrase "a view of one's own" evokes her famous essay A Room of One's Own and stresses the subjective character of her fiction. In a similar vein, in another letter, addressed to Lytton Strachey in February 1916, after the publication of her debut novel, Woolf confesses that she aimed: "to give feeling of a vast tumult of life, as various and disorderly as possible, which should be cut short for a moment by the death, and go on again - and the whole was to have a sort of pattern, and be somehow controlled. The difficulty was to keep any sort of coherence, - also to give enough detail to make the characters interesting" (1978: 82).

As a result, The Voyage Out abounds in experimental portraiture of the protagonist Rachel, a young woman with a musical talent, who encounters both love and death on her journey from Britain to South America. After her mother's death she is raised at Richmond by the sisters of her father, Willoughby Vinrace, who operates a shipping business. The novel opens with the preparations for the voyage to South America - soon Rachel sets off, accompanied by Willoughby, as well as her aunt and uncle, Helen and Ridley Ambrose. In Lisbon, the travellers are joined by Richard and Clarissa Dalloway. After being assaulted by Richard, Rachel is tormented by nightmares. In the meantime, the ship arrives in Santa Marina — Rachel

5 Cf. D. Massey. 2013. Space, Place and Gender. Hoboken: Wiley.

${ }^{6}$ Cf. R. Fivush. 2003. Autobiographical Memory and the Construction of a Narrative Self: Developmental and Cultural Perspectives. New York: Psychology Press. 
stays with the Ambroses, provided with "a room of her own." Woolf plays with the conventions of courtship narratives, introducing Terence and his friend St. John. Gradually, Rachel and Terence enter into a relationship and become engaged. When it seems that the plot will resolve in a happy ending, Rachel contracts a fatal illness and dies after days of delusions and coma. The novel ends with contradictory explanations for this death and a surrealistic scene of everyday life, observed by a half-asleep St. John.

The heroine of The Voyage Out is first represented within a network of gazes into her ship cabin and (auto)biographical memories. The meeting with her aunt Helen, brings around the following scene from the past:

"The last time I saw you, you were buying a piano," she continued. "Do you remember — the piano, the room in the attic, and the great plants with the prickles?"

"Yes, and my aunts said the piano would come through the floor, but at their age one wouldn't mind being killed in the night?" she enquired.

"I heard from Aunt Bessie not long ago," Helen stated. "She is afraid that you will spoil your arms if you insist upon so much practising."

"The muscles of the forearm - and then one won't marry?"

"She didn't put it quite like that," replied Mrs. Ambrose.

"Oh, no - of course she wouldn't," said Rachel with a sigh. (1991: 12)

In this short passage, the memories of Rachel and Helen overlap, spatially confined to Rachel's room, situated in the isolated space of the attic, as in other Woolf's novels. Both women adopt the observer perspective in their reminiscences - the fragmented, enumerated objects seem to be illuminated by the memory retrieval processes. The protagonist musical talent is introduced via the image of the piano, perceived by her relatives as a deadly abject. The musical passion is viewed as threatening the marital chances of Rachel, whose body does not conform to the Victorian 'Angel in the House'. The conflict between Rachel's struggle for independence and her upbringing is visible also in the memory of her mother's funeral, evoked by the scent of a broom. This Proustian memory is negated by her aunt, who arranges flowers and tries to persuade her that they are "cheerful" (1991: 29).

Nonetheless, the most important aspects of Rachel's characterization at the outset of the novel are her spatial portrayals 'painted' by two women - her aunt and Clarissa Dalloway, who haunts Woolf's fiction and becomes the eponymous character in her later novel. While depicting the unfamiliar private space of Rachel's cabin, both women adopt the environmental perspective, yet their portraitures are significantly different.

In Helen's description appears a striking simile, which draws upon the resemblance of "unprotected" sleeping Rachel to "a victim dropped from the claws of a bird of prey" (1991: 31). This victimized portrait may refer to heroine's upbringing, as Helen is afraid that her father is responsible for "nameless atrocities with regard to his daughter" and "bullying his wife" (1991: 17). The violence is further 
represented in Richard Dalloway's assault on Rachel in her cabin, which she leaves to escape him. The space is neither secure nor really private, as the only meaningful details are her personal belongings: the piano and books. After Richard's assault, Rachel is haunted by a nightmare of being caught in a claustrophobic tunnel and a vault, in which "she found herself trapped in [...], bricks meeting her whenever she turned, alone with a little deformed man who squatted on the floor gibbering" (1991: 74-75). Rachel wakes up and feeling terrified locks the door of her cabin, as "a voice moaned at her; eyes desired her. All night long barbarian men harassed the ship; they came scuffling down the passages, and stopped to snuffle at her door" (1991: 75). The oneiric imagery leaves open the question whether it refers to Richard, who tries to "invade" her cabin, or to her traumatized imagination.

Helen's description of Rachel's room on a ship is contrasted with Clarissa's spatial portrait. Like Settembrini in Mann's The Magic Mountain, Mrs Dalloway praises the beauty of human existence and wants to convince Rachel that "it [is] good to be alive" (1991: 55). When Rachel escapes both women, "who made her feel outside their world and motherless" and slams the door of her room, Clarissa "burst[s] them impulsively open" (1991: 53) and leaves ajar, thus blurring the boundaries between public and private space. She interrupts Rachel's interpretation of Bach's fugue and describes her cabin as "a dear little room," introducing Austenian narration to the novel. Again, the space of the room is only sketched: the door, the piano, the armchair, musical transcriptions, Cowper's and Brontë's books. It is significant that Clarissa conveys the symbolic messages for the protagonist after a quick scan of her room: "[s]he looked lightly round the room. 'I always think it's living, not dying, that counts," and later "everything's at one's feet. She glanced round as much as to say, "not only a few stuffy books and Bach" (1991: 54-55). Soon she convinces Rachel to walk with her on the deck.

As the ship cabin turns out to be neither private nor safe, Rachel decides to stay with Ambroses in South America - but only on condition that she is offered her own room. In its description, the narrative focus shifts from Helen, who calls it "a fortress as well as a sanctuary" (1991: 125) to Rachel. The contrast between a cramped cabin and a "large, private" room, evokes Woolf's juxtapositions of Victorian and Modernist spaces. Moreover, Helen's metaphors suggest such qualities as security, refuge and transcendence. The narration also underlines the metonymic relation between the room and the world, as Helen believes that for a woman this space could be the macrocosm. Nevertheless, in this idealized description, there are present troubling overtones in the allusions to Rachel's reading. The woman immerses herself in Ibsen's dramas, portraying the harsh reality hidden behind the "spotless" Victorian family and social system (in A Doll's House expressed in spatial metaphors). The juxtaposition between the "enchanted place, where the poets sang and things fell into their right proportions" (1991: 125) and Ibsen's realism is striking and lays the ground for Rachel's further disillusionment with Terence. 
In the relationship between these two people, autobiographical memory becomes the recurring theme. At the outset, their conversations oscillate between "the course of their past lives" (1991: 318) and their longings for "a world [...], where people knew each other intimately and thus judged each other by what was good" (1991: 309). Rachel's memories are highly gendered, as the experience of growing up as a woman is significantly different: "A girl is more lonely than a boy. No one cares in the least what she does. Nothing's expected of her" (1991: 228). Intriguingly, Terence's interest into Rachel's life is driven by a novelist's curiosity into this gendered dimension.

Woolf plays with the conventions of the Austenian novel, in which marriage is an inevitable ending. Instead, she shows how gender stereotypes undermine the relationship between Rachel and Terence, driving them away from the equal partnership they both long for. When Rachel plays Beethoven's sonata, Terence interruptes her, quoting from his emerging book Silence disturbing views on women who are optimistic, "because they don't think" and have "no sense of honour" (1991: 310-311). Ironically, Rachel's reply to these remarks is the same as the title of Terence's book: the silence. But a while later, an outburst discloses both her anger and a surprising belief in her musical genius:

"No, Terence, it's no good; here am I, the best musician in South America, not to speak of Europe and Asia, and I can't play a note because of you in the room interrupting me every other second."

"You don't seem to realise that that's what I've been aiming at for the last half-hour," he remarked. "I've no objection to nice simple tunes - indeed, I find them very helpful to my literary composition, but that kind of thing is merely like an unfortunate old dog going round on its hind legs in the rain." (1991: 311)

The metaphor of the dog is developed in A Room of One's Own, in which Woolf quotes Gray's infamous phrase "Sir, a woman's composing is like a dog's walking on his hind legs. It is not done well, but you are surprised to find it done at all" (2001: 46) as an example of prejudices against women artists.

After this exchange, a thread of understanding between Rachel and Terence is abruptly cut. It is textually mirrored in the disagreement in their memorial narratives of their first meeting:

"You fell in love with me," he corrected her. "You were in love with me all the time, only you didn't know it."

"No, I never fell in love with you," she asserted.

"Rachel — what a lie — didn't you sit here looking at my window — didn't you wander about the hotel like an owl in the sun -?"

"No," she repeated, "I never fell in love, if falling in love is what people say it is, and it's the world that tells the lies and I tell the truth. Oh, what lies — what lies!". (1991: 312-313)

Rachel's memory with direct field perspective ends with a repetition, which evokes "The horror! The horror!" - Kurtz's final words in Conrad's Heart of Darkness, as the truth about colonialism can be as devastating as about a patriarchal state. 
Nonetheless, before her premature death, the heroine experiences an epiphany of a significantly different character. This narrative starts when Rachel recalls "not only the night of the dance, but the entire past, tenderly and humorously, as if she had been turning in a fog for a long time" (1991: 335). She notices — from both environmental and observer's perspectives - the profound change in her perception of the room full of dancing people and the same but empty room. The former takes the shape of a scene, resembling a post-impressionist painting of "little red, excited faces, always moving, and people so brightly dressed," the latter seems "dim and quiet" (1991: 335). As the dance was often an allegory of human life, the image stimulates Rachel's existential reflection:

That was the strange thing, that one did not know where one was going, or what one wanted, and followed blindly, suffering so much in secret, always unprepared and amazed and knowing nothing; but one thing led to another and by degrees something had formed itself out of nothing, and so one reached at last this calm, this quiet, this certainty, and it was this process that people called living. Perhaps, then, every one really knew as she knew now where they were going; and things formed themselves into a pattern not only for her, but for them, and in that pattern lay satisfaction and meaning. (1991: 335)

Memory remains a force that gives the life story its unity and meaning - paradoxically, it becomes visible in Rachel's illness and subsequent death.

Rachel's malady has been interpreted spatially by scholars. Terentowicz-Fotyga notes that the protagonist distances herself from the world, while immersing into her mind. Rachel's semiosphere shrinks first to her room and then to her body (2006: 37). As Zink observes, the room becomes the metonymy for heroine's body (2013: 113). In the course of her illness, Rachel moves also from egocentric to the environmental perspective, as her room gains "an odd power of expanding, and though she pushed her voice out as far as possible until sometimes it became a bird and flew away, she thought it doubtful whether it ever reached the person she was talking to" (1991: 369).

Nevertheless, the processes of remembering and forgetting mirror the underlying conflict between the public and the private. From her earliest writings, Woolf develops her critique of British society, analyzing its collective memory and questioning the imposed public ways of remembering, which exclude women and other oppressed groups. In her memoir, she notes: "what immense forces society brings to play upon each of us" (1985: 80). When Rachel loses individual identity and memory, her room metamorphoses into a "semi-transparent" coffin. The space becomes absolute while the memory fades:

But for long spaces of time she would merely lie conscious of her body floating on the top of the bed and her mind driven to some remote corner of her body, or escaped and gone flitting round the room. All sights were something of an effort, but the sight of Terence was the greatest effort, because he forced her to join mind to body in the desire to remember something. She did not wish to remember; it troubled her when people tried to disturb her loneliness; she wished to be alone. (1991: 369) 
Paradoxically, in The Voyage Out memory becomes a retrospective and creative process that unifies and enables the existence, while oblivion brings death and annihilation.

\section{Final remarks}

The Voyage Out is marked by a desire to create a space for women. The heroine Rachel is a woman in her formative years, who struggles with the existential dilemmas and the need for personal fulfillment. Her representations are meticulously structured around the processes of autobiographical remembering and spatial perception, as her private rooms serve as loci of her memory and identity. In these "rooms of her own", she is able to reveal herself and develop her musical talents. Paradoxically, after Rachel experiences epiphany the convention of Bildungsroman is subverted and instead of growth and development, she experiences disintegration and death. Nonetheless, the heroines of Woolf's mature novels will "trespass" the walls of their rooms and achieve the flâneuse's freedom of "street haunting".

\section{References}

Bachelard, G. 1969. The Poetics of Space. Boston: Beacon.

Bal, M. 2009. Narratology. Toronto: Toronto University Press.

Bruś, T. 2011. "When the Self Portrays the Self: Composite Portraiture." Anglica Wratislaviensia 49. 9-17.

Eich, E., A.L. Nelson, M.A. Leghari, \& T.C. Handya. 2009. "Neural Systems Mediating Field and Observer Memories.” Neuropsychologia 47:11. 2239-2251.

Ender, E. 2005. Architexts of Memory: Literature, Science, and Autobiography. Ann Arbor: University of Michigan Press.

Fivush, R. 2003. Autobiographical Memory and the Construction of a Narrative Self: Developmental and Cultural Perspectives. New York: Psychology Press.

Marcus, L. 2004. Virginia Woolf. Tavistock: Northcote House.

Massey, D. 2013. Space, Place and Gender. Hoboken: Wiley.

Middleton, P. \& T. Woods. 2000. Literatures of Memory: History, Time, and Space in Postwar Writing. Manchester: Manchester University Press.

Mou, W. \& T.P. McNamara. 2002. "Intrinsic Frames of Reference in Spatial Memory." Journal of Experimental Psychology: Learning, Memory, and Cognition 28:1. 162-170.

Nalbantian, S. 2003. Memory in Literature. New York: Palgrave Macmillan.

Snaith, A. \& M.H. Whitworth (eds.). 2007. Locating Woolf: The Politics of Space and Place. New York: Palgrave Macmillan.

Terentowicz-Fotyga, U. 2006. Semiotyka przestrzeni kobiecych w powieściach Virginii Woolf. Lublin: Wydawnictwo UMCS.

Woolf, V. 1975-1980. The Letters. 6 vols. New York: Harvest-HBJ Books.

—. 1981-1985. The Diary. 5 vols. New York: Penguin Books.

—. 1991. The Voyage Out. London: Vintage.

-. 2001. A Room of One's Own. London: Vintage. 
Woolf, V. \& J. Schulkind. 1985. Moments of Being. San Diego: HBJ Books.

Zink, S.G. 2013. Virginia Woolf's Rooms and the Spaces of Modernity (doctoral dissertation King's College London). 